Archived version from NCDOCKS Institutional Repository http://libres.uncg.edu/ir/asu/

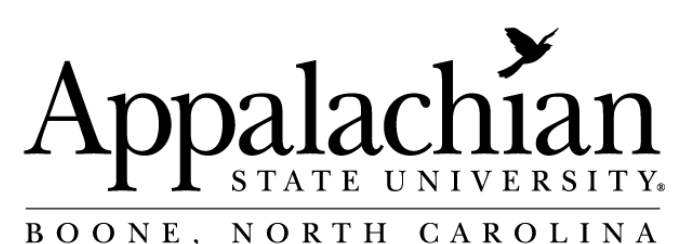

\title{
City Of God: Christian Citizenship In Postwar Guatemala
}

\author{
By: Timothy J. Smith
}

\begin{abstract}
Book Review of: City of God, by Kevin O'Neill.

Smith, Timothy J. (201 1). Review (invited) of City of God: Christian Citizenship in Postwar Guatemala, by Kevin Lewis O'Neill. American Anthropologist 113(4):689-690. https://doi.org/10.1111/ j.1548-1433.2011.01387_25.x. Publisher version of record available at: https:// anthrosource.onlinelibrary.wiley.com/doi/10.1111/i.1548-1433.2011.01387_25.x
\end{abstract}




\section{City of God: Christian Citizenship in Postwar Guatemala}

\author{
Timothy J. Smith \\ Appalachian State University
}

Although 14 years have passed since the end of the Guatemalan armed conflict, during which 200,000 people were killed or disappeared, the levels of violence and suffering today nearly match those during the war years. Concerns over murders, gang violence, and armed assaults underwrite participation (or lack thereof) in the electoral process by citizens who have come to accept that Guatemala is now Guatepeor. Many scholars have blamed both government corruption and citizen indifference as the catalyzing winds that have created the perfect storm for a lack of faith and hope in the future prospects for the scarred country. In this organic and provocative ethnography, Kevin O'Neill opens a window to the practices and promises of concerned citizens in Guatemala City (invisible in the literature until now) who are engaged in a powerful spiritual warfare against the moral failures and demons that continue to erode both soul and nation, accepting a responsibility for reversing the above trends.

The hook focuses on the neo-Pentecostal megachurches in war-torn Guatemala that have created an army of believers who are intent on reversing the increasing levels of violence through the production of an arsenal of morality that arms its soldiers with prayer and responsibility. Through an engaging ethnography of the daily practices and acts of members of the El Shaddai megachurch, O'Neill develops the concept of Christian citizenship for reimagining participation. Prayer and fasting arm these citizen-soldiers, providing them with a rationality that shapes their sense of participation, action, and belonging. His colorful vignettes of the faithful, massproduced sermons, and conflicting interpretations of what it means to be both a Christian and a citizen demonstrate that the public-private divide of citizenship and religious identity is weak at best, if not a fallacy. The actions of his informants complicate conventional understandings of citizenship, asking us to give consideration to their belief in defending the nation and shaping spiritual landscapes for future battles.

In the first three chapters, O'Neill expands on traditional scholarly analyses of citizenship, participation, and the citizen-soldier, developing his concept of Christian citizenship with a well-balanced movement from theory to ethnography and back (at times efficiently blurring the walls between the two, which tend to doom many first ethnographies). Testimonies and descriptions of the everyday strengthen 0 'Neill's focus on the construction of this citizen- ship as a type of subjectivity informed by the moral teachings, responsibility, and rationality espoused by both leaders and followers within El Shaddai' s growing Hock. Through a vivid description of the acts of citizenship performed by followers and the spaces in which they take place, O'Neill relies on the metaphor of weight, which he presents as the "experience of something pressing down on someone to communicate the felt reality of responsibility" (p. 5). For the followers of El Shaddai, this moral responsibility is one borne on the backs of neo-Pentecostals who choose to understand the woes of Guatemala as having to do with a lack of faith and spiritual practice rather than historical or structural factors.

The last three chapters highlight other areas in which the reader will find El Shaddai's citizen-soldiers wielding their swords. Chapter 4 is an interesting and well-situated study of the conscripts of performed masculinities, in which fathers (as opposed to mothers) take on the added burden of passing on moral values and teachings to their children. Although chapter 5 takes the reader out of Guatemala City and into the countryside, illuminating El Shaddai's philanthropic work in rural indigenous communities (and the construction of ethnicity in postwar Guatemala), chapter 6 explores a particular framing with which Guatemalan neo-Pentecostals see their struggle as one that is international, requiring one battle, one nation at a time. The hook ends with a conclusion centered on "disappointment," acknowledging that 
many scholars of political process, citizenship, and democratization will find the efforts and actions of neoPentecostal Guatemalans frustrating and futile with regards to change in patterns of violence and crime. However, he urges the reader to stray from such skepticism and reimagine what citizenship may or may not entail.

Although the City of God is not a traditional study of citizenship, it does raise interesting questions regarding how scholars have historically defined and worked through the complicated network of participation, voice, selfhood, belonging, democracy, and the construction of identity normally ascribed to voting and the electoral process. O'Neill provides a nuanced and fresh take on particular meanings that both shape and emerge from citizenship, and he is clear that this is neither a study of Christianity per se, nor a treatise on Christian politics and its leaders. He is trying to look beyond the static paradigms that have guided our understanding of participation and citizenship. His book is an important and innovative contribution that will add greatly to the growing literature on structural violence in postwar Guatemala and citizen responses to the rise in crime and insecurity. It also represents a response to the ethnographic lacunae of scholarship on evangelical Christianity in Guatemala, which normally analyzes conversion as either tied to develop-ment opportunities for the disempowered or as a pragmatic response to the repression during the armed conflict. Finally, this work offers another much-needed ethnography of Guatemala City itself (there is a small but growing body of literature) without dissolving into the air of theory and irrelevant transnational framings. 